Portland State University

PDXScholar

$1-1-2006$

\title{
A Cooperative Publishing Model for Sustainable Scholarship
}

Robert Schroeder

Portland State University, schroedr@pdx.edu

Gretta E. Siegel

Portland State University, bvsg@pdx.edu

Follow this and additional works at: https://pdxscholar.library.pdx.edu/ulib_fac

Part of the Library and Information Science Commons

Let us know how access to this document benefits you.

\section{Citation Details}

Schroeder, Robert and Siegel, Gretta E., "A Cooperative Publishing Model for Sustainable Scholarship" (2006). Library Faculty Publications and Presentations. 66.

https://pdxscholar.library.pdx.edu/ulib_fac/66

This Pre-Print is brought to you for free and open access. It has been accepted for inclusion in Library Faculty Publications and Presentations by an authorized administrator of PDXScholar. Please contact us if we can make this document more accessible: pdxscholar@pdx.edu. 


\title{
A Cooperative Publishing Model for Sustainable Scholarship
}

\author{
ROBERT SCHROEDER and GRETTA E. SIEGEL \\ Portland State University Library \\ Published in Journal of Scholarly Publishing, Volume 37, Number 2, January 2006, pp.86-89 \\ 10.1353/scp.2006.0006
}

Organizing scholarly publishing as a cooperative business has the promise of making journals more affordable and scholarly publishing more sustainable. The authors describe the development of the modern cooperative from its beginnings in England during the Industrial Revolution and highlight the great extent and diversity of business worldwide that is currently done cooperatively. Some of the current initiatives in scholarly publishing (SPARC, PLoS, German Academic Publishing, etc.) are analysed in light of cooperative business principles, and it is shown that, while these models often partially utilize cooperative business practices, none of them has adopted the cooperative model in totality.

A cooperative can be defined for practical purposes as a democratic association of persons organized to furnish themselves an economic service under a plan that eliminates entrepreneur profit and that provides for substantial equality in ownership and control.

The current state of scholarly publishing can best be defined as 'transitional.' For the past two decades we have been moving from print to electronic dissemination formats, from well-defined economic models that, for the most part, served the learned and research communities to wideranging models that span the spectrum from elitist to populist to everything in between. The past two years have been particularly interesting to anyone following the 'open access' trend, which, in varying ways (still ranging from elitist to populist), is attempting to broaden access to scholarly output while maintaining fiscal solvency, if not profit.

According to Association of Research Libraries (ARL) statistics, from 1986 to 2004 serials expenditures in ARL libraries have increased 273 per cent, while the Consumer Price Index went up only 73 per cent over the same period. ${ }^{2}$ The current problem is that the 'circle of gifts' that Anne Okerson so elegantly described in her 1992 article, which she wishfully projected would embrace the digital wave and continue on as a circle, evolved in a way that has developed a weak link, that of egregious price setting and huge profit motives by commercial (and some society) publishers. ${ }^{3}$ Will the circle be unbroken? This is a question that can be answered only by the communities of scholars who are ready to take on ownership of the fruits of their labour. This article presents a tested model that, if applied to the current world of electronic scholarly publishing, could answer that question in the affirmative.

Scholarly journal publication has five major facets: product development, production, marketing, distribution, finance, and general administration. ${ }^{4}$ Most of these facets are similar in the traditional print journal realm and in the electronic realm, the only differences being that many processes take place more quickly in the digital environment. Product development for a new journal begins conceptually with the recognition of the need for a new publication and the development of a new publication's scope and niche. Next, an editorial board is commissioned and general editors, outside referees, and copy editors are found, all of whom will assure quality control. Articles are solicited from the scholarly community and the editing and vetting process begins. Once the requisite number of acceptable articles for an issue is produced, production commences. The authors' print and graphic components are reformatted to adhere to the design and computer standards of the publication, and the article is included in the journal's online 
version and, later, in its digital archive. Production may also include the abstracting and indexing of articles for future retrievability. Marketing and promotion of a new journal begins soon after a journal's conception and continues through a publication's run. Electronic distribution and order fulfilment begin as soon as subscription orders arrive.

The last two facets of journal publishing, finance and administration, are not part of the publication cycle per se but may be considered as overhead. The finance department sets the price of subscriptions and deals with accounting, legal, and tax matters. General administration oversees the publishing cycle and manages and coordinates the business operations.

Private businesses and scholarly communities have published scholarly journals for many years, but what would be the benefits of publishing them cooperatively? In order to answer that question, we must first understand what the cooperative business model is and where it comes from. Cooperatives are much more than neighbourhood natural food stores or grain elevators. While these are examples of cooperatives, we must understand what they have in common and how they came to exist.

The modern cooperative movement originated during the Industrial Revolution in Britain. The huge transformation of industry and the economy caused upheaval and great hardships among the workers in many occupations. Traditional individual craftsmen were losing their jobs to mechanized factories, while historically common lands were being privatized. In the north of England, by the early 1800s, 'life expectancy had dropped over recent decades from 35 years to 21 years, ${ }^{5}$ and the wages of a handloom weaver dropped from thirty shillings per week in 1797 to five shillings and sixpence by $1830 .{ }^{6}$ Newly industrialized workers were forced to purchase goods at inflated prices at the company 'truck and badger' shops and were going deeper and deeper into debt. Philosophers and social reformers like Robert Owen began to see cooperation as a potential way to free the workers from their poverty. In the early 1800s Owen set up shortlived cooperative ventures in New Lanark and Orbiston in Scotland, and in New Harmony, Indiana. Dr William King, founder of a cooperative store, published the newspaper The Cooperator for two years, beginning in 1827, and gave a voice to the burgeoning cooperative movement.

On 15 August 1844 in Rochdale, England, a group of twenty-eight weavers and other tradesmen came together for what was to be a momentous event. In order to free themselves from their cycle of poverty, and in order to purchase affordable and unadulterated food, they formed the Rochdale Society of Equitable Pioneers. They had raised £28, and with it they rented a storefront and purchased twenty-eight pounds of butter, fifty-six pounds of sugar, 600 pounds of flour, a sack of oatmeal, and some candles. Their cooperative store was not the first of its kind even in Rochdale, but, because of the unique cooperative principles upon which it was founded, it was to be the most enduring and important one.

The original Rochdale Principles, as they have come to be known, were these: 'democratic control; one member one vote and equality of the sexes; open membership; pure unadulterated goods; no credit; profits to be divided on the amount of purchase made; a fixed rate of interest on investment; promotion of education; and political and religious neutrality. ${ }^{7}$ These principles have been reviewed, revised, and affirmed over time, and the latest version, issued in 1995 by the International Cooperative Alliance, is as follows: voluntary and open membership; democratic member control; member economic participation; autonomy and independence; education, training, and information; co-operation among cooperatives; and concern for community. ${ }^{8}$ These principles are at the core of what makes cooperative businesses unique, powerful, and successful. Control of the business is shared equally among the members of a cooperative, membership is voluntary and limited to the producers or consumers of a product or service, the economic benefits of cooperation return to the members equitably, and because there is limited return on investment and the profit motive is non-existent, prices remain low. ${ }^{9}$ 
These unique principles have made cooperative businesses successful worldwide. In Britain in 1864 there were 100,000 members of cooperatives with $£ 2.5$ million in sales, ${ }^{10}$ and by 1993 there were eight million co-op members doing $£ 7$ billion in retail trade. ${ }^{11}$ In 1993 in the European Union there were 45,000 worker cooperatives employing 750,000 people, ${ }^{12}$ and worldwide there were estimated to be 800 million cooperative members and 100 million people employed in cooperatives. $^{13}$

The cooperative movement has thrived in the United States as well. By 1985 there were 4.78 million members of farmer cooperatives, ${ }^{14}$ and in 1987 agricultural cooperatives had \$43 billion in sales of food and $\$ 14$ billion in sales of farm supplies. ${ }^{15}$ In 2000 mutual insurance companies accounted for almost 20 per cent of the life insurance in force in the United States (over \$3 billion), ${ }^{16}$ and, according to the National Credit Union Administration Annual Report 2004, there were 9012 credit unions in the United States with $\$ 647$ billion dollars in total assets. ${ }^{17}$ The range of cooperative business is huge. There are consumer co-ops, housing co-ops (including condominiums), credit unions, savings and loan associations, mutual insurance companies, marketing co-ops, utility co-ops, and agricultural co-ops. Some would even include trade associations and unions as cooperative associations. ${ }^{18}$ If all these different types of businesses can organize and flourish cooperatively, why not scholarly publishing?

Non-commercial dominance of the scholarly publishing arena has historical precedent. From the beginning of scholarly publishing in 1685 with the publication of the Royal Society of London's Philosophical Transactions, and for at least the first two hundred years, scholarly publication, to a great extent, remained in the hands of scholars. In the United States, until 1945, almost all of the technical and scholarly journals were published by professional societies. ${ }^{19}$ And while in Europe most of the scholarly publication is done by commercial firms, in 1995 commercial publishers accounted for only 40 per cent of scholarly scientific journals in the United States; 43 per cent continued to be published by university presses or by professional or learned societies. ${ }^{20}$

To a great extent these non-commercial entities already understand the publishing business and publishing processes. There are many models for successful publication in existence, and the lack of technology or knowledge of the process is not the issue. The community of scholars knows full well that they are both producers and consumers of the output of their research; they just do not, at this time, control its dissemination. What is lacking is the collective will of the scholarly community to create a sustainable structure that will ensure access to fairly priced publications now and in the future. Cooperative university-supported publishing could accomplish this.

The cooperative business model would sustain publishing in a variety of ways. Democratic control and a limited return on investment would assure that prices rise only enough to cover expenses. Universities and their faculty are in a unique position in that we are the primary producers and consumers of scholarly work. It is in our best interest to keep all production and distribution costs down - the return on our investment will primarily come in continued lower prices for our quality scholarly product. Within the scholarly communities at most universities are experts who already perform, or know how to perform, many of the functions of electronic publishing. Faculty already edit, referee, index, and create online repositories for publications. They could work part time in the publishing cooperative alongside paid workers, thus further decreasing the cost of publication. There are many other faculty well versed in database creation and networking, as well as in marketing, sales, and accounting. For faculty in aligned disciplines - such as those in writing and publishing programs, business administration, and library science - there is a natural fit for engaging in publishing activities and even in the scholarship of publishing. Participating universities' recognition of this scholarship in the faculty evaluation process would greatly facilitate participation by junior faculty members. While faculty in other 
fields - the sciences, humanities, and social sciences - are establishing and maintaining their intellectual presence in their respective fields of research, there will be some, generally senior, faculty who may choose, and could be encouraged, to take their prior experiences of writing, editing, and peer review a step further to actively engage with other activities in the publishing enterprise.

In these ways, not only could faculty contribute their talents, they could also disseminate new models and ideas of scholarly publishing to others. This task dovetails with the cooperative principle of 'education, training, and information.' The scholarship of publishing would also allow experts to teach new cooperative members how to start up and maintain their own new publications within the cooperative. This outreach and support aligns with the cooperative principle of 'cooperation among cooperatives'.

The current state of scholarly publishing is one of flux. The rallying cry over the past few years has been that the publishing models of the past decade or so have created an unsustainable environment. Experiments are being tried and new models tested. The following comments offer a brief look at some of these experiments and models in the context of established cooperative principles that have been successful in other arenas of enterprise and commerce. In Table 1, the far left column lists cooperative principles that seem appropriate to the area of publishing, as well as a few more related 'desirable' principles that would help to round out the picture of what an ideal cooperative model for publishing might look like. The rest of the table identifies which of these principles or characteristics are being met by some of the current 'en vogue' models. Discussion of these follows. 
Table 1

Cooperative/desirable principles for publishing models

\begin{tabular}{|c|c|c|c|c|}
\hline & SPARC & Open Access & $\begin{array}{l}\text { Profit } \\
\text { Driven }\end{array}$ & GAP \\
\hline \multicolumn{5}{|l|}{ Basic co-op principles* } \\
\hline Democratic member control & & & & partial \\
\hline $\begin{array}{l}\text { Voluntary and open } \\
\text { membership }\end{array}$ & $\mathrm{X}$ & & & $\mathrm{X}$ \\
\hline $\begin{array}{l}\text { Member economic } \\
\text { participation }\end{array}$ & $\mathrm{X}$ & & & $\mathrm{X}$ \\
\hline $\begin{array}{l}\text { Pure unadulterated goods } \\
\text { (quality control) }\end{array}$ & $\mathrm{X}$ & $\mathrm{X}$ & $\mathrm{X}$ & $\mathrm{X}$ \\
\hline Autonomy and independence & $\mathrm{X}$ & & & $\mathrm{X}$ \\
\hline $\begin{array}{l}\text { Limited return on Investment } \\
\text { (no profit motive) }\end{array}$ & $\mathrm{X}$ & $\mathrm{X}$ & & $X$ \\
\hline $\begin{array}{l}\text { Benefit proportional to } \\
\text { contribution }\end{array}$ & & & & $X$ \\
\hline $\begin{array}{l}\text { Promotion of education, } \\
\text { training, and information } \\
\text { Cooperation among } \\
\text { cooperatives }\end{array}$ & $\mathrm{X}$ & & & $\mathrm{X}$ \\
\hline Concern for community & $\mathrm{X}$ & $\mathrm{X}$ & & $\mathrm{X}$ \\
\hline $\begin{array}{l}\text { Other related desirable } \\
\text { principles for publishing models }\end{array}$ & & & & \\
\hline $\begin{array}{l}\text { Appropriate and integrated } \\
\text { application of diverse } \\
\text { expertise }\end{array}$ & & & & $X$ \\
\hline $\begin{array}{l}\text { Sustainability (or the goal of } \\
\text { same) }\end{array}$ & $\mathrm{X}$ & $\mathrm{X}$ & $\mathrm{X}$ & $\mathrm{X}$ \\
\hline High visibility/access & $\mathrm{X}$ & $\mathrm{X}$ & $\mathrm{X}$ & $\mathrm{X}$ \\
\hline
\end{tabular}

* $\quad$ From the original Rochdale Principles or the 1995 International Cooperative Alliance

\section{SPARC}

The Scholarly Publishing and Academic Resources Coalition (SPARC) is an alliance of universities, research libraries, and organizations. Their agenda within the scholarly publishing arena is threefold: (1) 'Incubation of competitive alternatives to current high-priced commercial journals and digital aggregations'; (2) 'Public advocacy of fundamental changes in the system and the culture of scholarly communication'; and (3) 'Education campaigns aimed at enhancing awareness of scholarly communication issues and supporting expanded institutional and scholarly community roles in and control over the scholarly communication. ${ }^{21}$ In these efforts, the work of SPARC, while not exactly a co-op model, does acknowledge the cooperative values of care for the community, quality control, education and information, support for the non-profit sector, open membership, sustainability, and high visibility/access.

\section{Open Access}

Open access models, such as those put in place by the Public Library of Science (PLoS) or PubMed, are the types supported by SPARC. These differ somewhat in that PLoS is a 
commercial venture and PubMed is government based, but both share the approach that the results of scholarly research should be made freely available to the public. The definition of 'open access,' as drafted at the Bethesda Meeting of 2003 and adopted by PLoS, is as follows:

An Open Access Publication is one that meets the following two conditions:

The author(s) and copyright holder(s) grant(s) to all users a free, irrevocable, worldwide, perpetual right of access to, and a license to copy, use, distribute, transmit and display the work publicly and to make and distribute derivative works, in any digital medium for any responsible purpose, subject to proper attribution of authorship, as well as the right to make small numbers of printed copies for their personal use.

A complete version of the work and all supplemental materials, including a copy of the permission as stated above, in a suitable standard electronic format is deposited immediately upon initial publication in at least one online repository that is supported by an academic institution, scholarly society, government agency, or other well-established organization that seeks to enable open access, unrestricted distribution, interoperability, and long-term archiving (for the biomedical sciences, PubMed Central is such a repository). ${ }^{22}$

Implicit in this definition is the principle of care for the community, as the purpose of such a definition is to remove access barriers and allow the free flow of information. The requirement for immediate deposit into a digital repository demonstrates the lack of an ongoing profit motive, though of course there are costs to be covered in the initial publication of these works. Most journals that publish 'open access' articles are not member-based, so the principles of democratic control, member economic participation, and related other principles do not really apply to this model. An aggregator, such as BioMed Central, that specializes in the publication of open access journals could be in a position to adopt more of these member-oriented principles and possibly approach a true co-op model, should they be interested in exploring this route.

\section{Profit Driven}

Recently, premier scientific imprints such as Elsevier, Springer, and Kluwer have responded to market pressures by offering 'deals' to offset wholesale cancellations of journal subscriptions. They have offered libraries broader access to lists of titles in exchange for reduced cancellations of existing subscriptions and for transferring all existing subscriptions to electronic access only. There are variations on this theme, and while quality control and high visibility are maintained, and while the sustainability of the publishing companies is improved, there is by no means any kind of commitment to any other cooperative principles.

\section{GAP}

As far as we are aware, the model most closely aligned with established cooperative principles to date is that of the German Academic Publishers Project (GAP). ${ }^{23}$ GAP's purpose is to set up a cooperative consortium of academic presses, scholarly societies, universities, academic departments, and even individuals. The project's focus is on infrastructure rather than content. The stated goals are cooperation, sustainability, quality control (peer review), online publication (high visibility), and open access. Mostly for tax reasons, GAP has adopted a member-based model (in German, eingetragener Verein), with voluntary and mostly open membership (the project reserves the right to deny memberships). ${ }^{24}$ While there is democratic involvement on some levels of operation and the benefits are proportional to the contribution made, GAP is not organized as a legal cooperative, which means that ongoing democratic control is not assured. 
The organization provides training workshops and information on electronic and scholarly publishing, as well as assistance to entities wanting to become members. The structure of the project involves a 'back office' (which provides technical services such as document storage, metadata transfer, support for universities wanting to start new presses, and the basic publication mechanisms) and multiple 'front offices,' which are the members utilizing the 'back office.' Members are able to contribute expertise on the various aspects of running the 'back office,' which makes the GAP model much closer to a true cooperative.

$* * *$

Historically, the society model of publishing came very close to the cooperative model, in that profit was not generally a motive and the academic producer/consumer engaged in all five of the major facets of production and distribution, especially if the society publication was based at an academic institution. When production and distribution became too burdensome, however, many societies turned these aspects over to commercial entities, and the model became much less cooperative. Now that all these processes can be carried out electronically, however, the time is ripe for a more radical paradigm shift than what is offered by many of the 'open access' models we are now seeing.

Many of the publishing models discussed above (SPARC, GAP, etc.) came about as a reaction to the economic burden placed on libraries over the past few decades by rising serials costs, and they have demonstrated that there are alternatives to for-profit publishing. The cursory analysis of the trends presented here makes it clear that there are basically two divergent approaches at work. One is the attempt to make for-profit models more sustainable, while the other puts the publication and dissemination of scholarship back into the hands of scholars. It is also clear that the latter approach can be successful only with the participation of many, thus leading to the promise of the more cooperative and democratic ventures being attempted. From the desperation of the Industrial Revolution, the weavers of Rochdale England found a way to supply themselves with the necessities of life. Millions of people have met needs - from electricity to housing, from banking to farming - through the thousands of cooperative societies and ventures that have since prospered. Should the scholarly communities of additional countries adopt the GAP model, or something similar, and from there form a global partnership of a 'cooperative of cooperatives,' there may be some hope for a truly sustainable model of scholarly publishing.

ROBERT SCHROEDER is a reference and instruction librarian at Portland State University and the Coordinator of Information Literacy. He has been actively involved in many cooperative ventures for the past thirty years.

GRETTA SIEGEL is the Science Librarian and Coordinator for Scholarly Communication Initiatives and Outreach at Portland State University. She has been wrestling with the economic vagaries of scholarly publishing for most of her more-than-twenty-year career.

1 Israel Packel, The Organization and Operation of Cooperatives; Including Consumer, Marketing, Purchasing, and Trade Associations, Labor Unions and Condominiums (Philadelphia: Joint Committee on Continuing Legal Education of the American Law Institute and the American Bar Association 1970), 2

2 'Monographs and Serials Costs in ARL Libraries 1986-2004,' in ARL Statistics 2003-04 (Washington, DC: Association of Research Libraries), http://www.arl.org/stats/arlstat/graphs/2004/monser04.pdf 
Ann Okerson, 'The Missing Model: A “Circle of Gifts,”' Serials Review 18, 1/2 (Spring/Summer 1992): 92-6 For the following discussion we have relied on Gillian Page, 'The Economics of Traditional Journal Publishing,' in Hazel Woodward, ed., The International Serials Industry (Aldershot, UK: Gower 1993): 61-87, and Sally Morris, 'Who Needs Publishers,' Journal of Information Science 25, 1 (February 1999): 85-8.

Tom Cannon, The Ultimate Book of Business Breakthroughs: Lessons form the 20 Greatest Business Decisions Ever Made (Oxford: Capstone 2000), 238

John Barnett, Plenty and Want: A Social History of Diet in England from 1815 to the Present Day (London: Scolar Press 1979), 51

Cannon, Ultimate Book, 240

International Co-operative Alliance, 'What Is a Co-operative?' (International Co-operative Information Centre, 8 January 1996), www.wisc.edu/uwcc/icic/def-hist/def/what-is.html

Packel, Organization and Operation of Cooperatives, 4-5

John Birchall, Co-op: The People’s Business (Manchester, UK: Manchester University Press 1994), 65

'150 Years of the Co-op,' New Statesman and Society (17 June 1994): iii-iv

Ibid., vii

International Co-operative Alliance, 'Dimensions of the International Co-operative Movement' (International Cooperative Information Centre, 1995), http://www.wisc.edu/uwcc/icic/def-hist/def/dim-int.html

John A.C. Hetherington, Mutual and Cooperative Enterprises: An Analysis f Customer-Owned Firms (Charlottesville: University Press of Virginia 1991), 108

Ibid.

Institute of Life Insurance, Life Insurers Fact Book 2001 (New York: Institute of Life Insurance 2001), 3

National Credit Union Administration, Annual Report of the National Credit Union Administration 2004 (Alexandria, VA: National Credit Union Administration 2004), http://www.ncua.gov/ReportsAndPlans/annualrpt/2004AR.pdf, 1078

Packel, Organization and Operation of Cooperatives, 11-23

Carol Tenopir and Donald W. King, Towards Electronic Journals: Realities for Scientists, Librarians, and Publishers (Washington, DC: Special Libraries Association 2000), 60

Carol Tenopir and Donald W. King, 'Trends in Scientific Scholarly Journal Publishing in the United States,' Journal of Scholarly Publishing 28, 3 (April 1997): 135-70, 136

Judith Matz and Kaylyn Hipps, eds., 'Scholarly Publishing and Academic Resources Coalition,' ARL Program Plan 2002 (Washington, DC: Association of Research Libraries 2002), http://www.arl.org/arl/pp2002/pp12.html 'Bethesda Statement on Open Access Publishing,' The SPARC Open Access Newsletter, http://www.earlham.edu/ peters/fos/bethesda.htm (explanatory footnotes omitted)

Kim Braun, 'The German Academic Publishers Project - GAP,' in Sely Maria de Souza Costa, et al., eds., From Information to Knowledge: Proceedings of the 7th ICCC/IFIP International Conference on Electronic Publishing held at the Universidade do Minho, Portugal, 25-28 June 2003, (Minho: Universidade do Minho 2003), http://elpub.scix.net/cgi-bin/works/Show?0323

Kim Braun, 'GAP - German Academic Publishers: A Network Approach to Scholarly Publishing,' Canadian Journal of Communication 29, 3/4 (2004): 301-15, 307; Kim Braun, e-mail to author, 5 August 2005 